\title{
New Concept for Museum Storage Buildings - Evaluation of Building Performance Model for Simulation of Storage
}

\author{
Christensen, Jørgen Erik; Knudsen, Lise Ræder ; Kollias, Christos Georgios
}

Published in:

2016 International Conference on Architecture and Civil Engineering.

Publication date:

2016

Document Version

Peer reviewed version

Link back to DTU Orbit

Citation (APA):

Christensen, J. E., Knudsen, L. R., \& Kollias, C. G. (2016). New Concept for Museum Storage Buildings Evaluation of Building Performance Model for Simulation of Storage. In 2016 International Conference on Architecture and Civil Engineering. International Conference on Architecture and Civil Engineering. Annual Proceedings

\section{General rights}

Copyright and moral rights for the publications made accessible in the public portal are retained by the authors and/or other copyright owners and it is a condition of accessing publications that users recognise and abide by the legal requirements associated with these rights.

- Users may download and print one copy of any publication from the public portal for the purpose of private study or research.

- You may not further distribute the material or use it for any profit-making activity or commercial gain

- You may freely distribute the URL identifying the publication in the public portal 


\title{
New Concept for Museum Storage Buildings
}

\author{
Evaluation of Building Performance Model for Simulation of Storage
}

\author{
Jørgen Erik Christensen ${ }^{1}$ Lise Ræder Knudsen ${ }^{2}$ Christos Georgios Kollias ${ }^{3}$ \\ Department of Civil Engineering ${ }^{1}$ Conservation Centre Vejle ${ }^{2}$ Twin and Earth Limited, Exmouth House ${ }^{3}$ \\ Technical University of Denmark ${ }^{1}$ Cultural Heritage Centre Vejle ${ }^{2}$ 3-11 Pine Street $^{3}$ \\ DK-2800 Kongens Lyngby, Denmark ${ }^{1}$ DK-7100 Vejle, Denmark ${ }^{2}$ London EC1R 0JH, UK ${ }^{3}$ \\ jerik@byg.dtu.dk11rk@konsv.dk² christos.kollias@twinearth.co.uk ${ }^{3}$
}

\begin{abstract}
Museums keep and protect a part of our material cultural heritage for future generations; however the museums only exhibit a little part of their collections and most of the objects are kept in storage. Unfortunately the climates of many storage rooms are not ideal for keeping the chemical and physical decay of the objects as low as possible. Museum storage buildings should be able to provide a considerable stable indoor environment in terms of temperature and relative humidity. This paper explores how to simulate and build low energy museums storage buildings, and the paper shows that it is possible to make a building of low building expenses, very low running expenses and very high quality. In addition it is described that the energy consumption is only $2 \%$ compared to normal HVAC solutions, and the $2 \%$ can be delivered by excess wind power from Danish windmills resulting in that the building is close to be $\mathrm{CO}_{2}$ neutral. The analysis shows very good agreement between simulations and measurements, meaning that the proposed methods can be used for designing museum storage buildings. The analysis also shows, that the weather conditions of previous years, affect the indoor environment of the following years.
\end{abstract}

Keywords-component; museum storage; dehumidification; energy efficiency; conservation conditions; airtightness; $\mathrm{CO}_{2}$ neutral building

\section{INTRODUCTION}

Museums keep and protect a part of our material cultural heritage for future generations. Most people have seen works of art and objects describing our history in the exhibitions of the museums. However the museums only exhibit a little part of their collections. Many, many objects, works of art and natural historic specimens are kept in storage, where they serve as a "gold chamber" of research possibilities and new stories to be told in the museums exhibitions for our children and grandchildren.

The objects and art, which are not in exhibition, are kept in museums storage. Often the climates of the storage rooms are not ideal for keeping the chemical and physical decay of the objects as low as possible. The funding of museums is often limited and therefore most attention is given the exhibition, which is the visible part for visitors and donators. The expensive task of keeping good storage for the collections not on display is sometimes neglected or it is postponed to next year - every year, Fig. 1 .

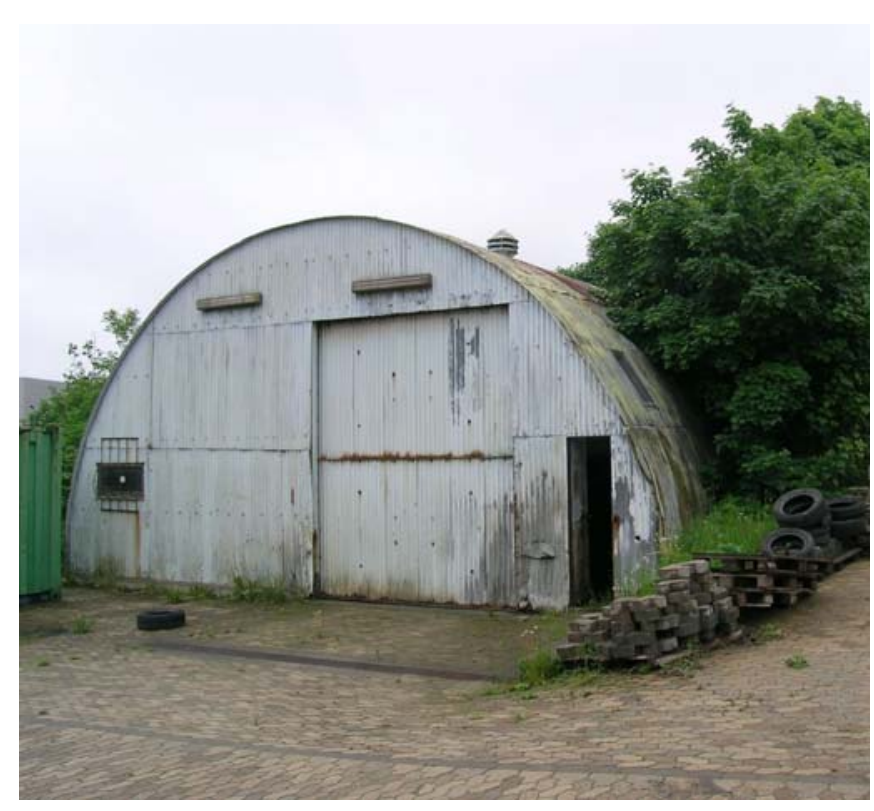

Figure 1. Museum storage building of inadequate quality. (Photo: Camilla Bastholm).

A good storage building for most museums objects must have a stable relative humidity of about $40-50 \%$ and a temperature which does not exceed $18^{\circ} \mathrm{C}[1, \mathrm{p} .4]$.

This paper explores a new purpose built low energy museum storage building and it will show that it is possible to make a building of low building expenses, very low running expenses and very high quality. Furthermore, the paper pose the question: "Why do so many museums choose an old and very energy consuming building for storage, when research has shown that the "Danish low-energy Museums storage building" saves 98\% of the energy used in conventional museum storage buildings?"

This paper first describes examples of the consequences of inadequate storage buildings and what kind of damage that will occur. Then is described the design of a new concept for a museum storage building, which is able to provide a considerably stable indoor environment in terms of temperature and relative humidity (RH) [2]. 


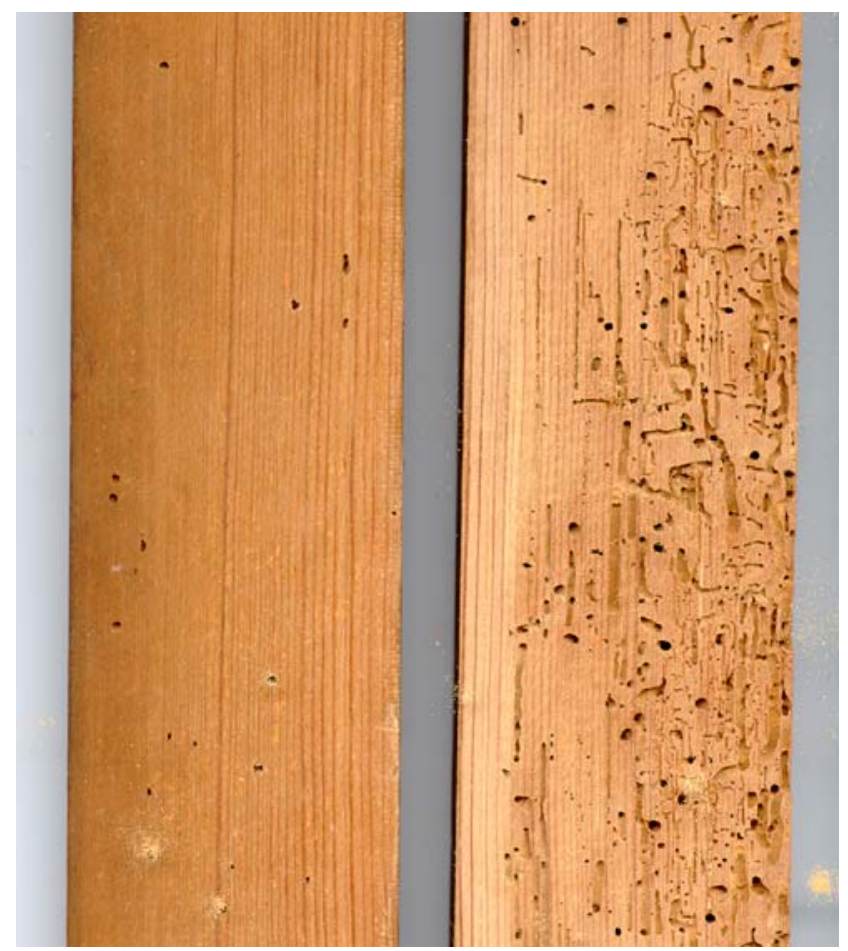

Figure 2. Left: Surface of a frame of a painting eaten by wordworms. Only a few holes in the frame is seen. Right: The same piece of frame after planning. Beneath the surface the frame is sizably damaged. Woodworms and other pests are common in humid storage facilities of museums. (Photo: Lise Ræder Knudsen)

\section{A. Inadequate storage buildings in the short run are expensive buildings in the long end}

When objects of different materials are stored under inadequate conditions for years, many different damages occur. There can be attacks by pests. Woodworms eat wooden objects, Fig. 2. Moth, larder- and carpet beetle eat textiles, leather and fur; mold is growing on the objects of all materials, Fig. 3 and major structural damage of the objects will occur due to high or too low relative humidity, Fig. 4. Furthermore, mold-infected objects can provoke allergic reactions among the museum staffs. It is thus important to store objects under controlled and stable conditions.

In 2006, a national survey [3] described the storage facilities of 127 state-supported museums in Denmark. The result was that about $1 / 3$ of the storage rooms were good, $1 / 3$ could be refurbished to serve as good storage rooms and $1 / 3$ was of such low quality, that they were destructive to the cultural heritage instead of protecting it. These storage rooms should be abandoned [3]. Furthermore, in 2013 a report from the National Audit Office expressed critique of the statesupported museums' ability to protect the cultural heritage based on several cases of bad storage facilities [4, p.12]. Inadequate museums storage buildings are thus a frequently occurring problem.

Different materials have different requirements of storage, when the goal is to avoid degradation. To some degree, a low temperature below $18{ }^{\circ} \mathrm{C}$ with only slow fluctuations and a stable relative humidity between $40-50 \%$ prevents chemical degradation and pests. Furthermore, easy access into the storage without stairs and narrow doors prevent damage due to transportation, and rooms without water pipes and other risks of flood will prevent or reduce the risk of water damage. The requirements of museum storage buildings are not difficult to achieve, but often inadequate buildings require extensive dehumidification, and other refurbishments which are costly. Often museums are offered very cheap buildings for storage old buildings that no one else would like to use. Since the museums often are short on money and there is a lack of knowledge of the loss and expenses, which are the consequences of bad storage facilities, inadequate buildings are often taken into use as storage facilities.

Recently a project was initiated on moving the collection of Copenhagen Museum and Archives in Denmark to a new building after many years of neglect. Much of the collection was infected with mold and severely damaged by too humid and changing climate in the old storage buildings. The cost alone of cleaning mold, registration, packing and moving the collections was estimated to 28 million DKK (3.8 million $€$ ) [5].

\section{It can be concluded that:}

- Many Danish museums have problems with inadequate storage facilities.

- Objects meant to be preserved for future generations are instead degraded and need conservation due to low quality of the storage buildings and insufficient climate control.

- Changing this can be very expensive.

When discussing these conclusions with conservation professionals from other parts of the world, it seems that these problems are currently occurring in other countries as well.

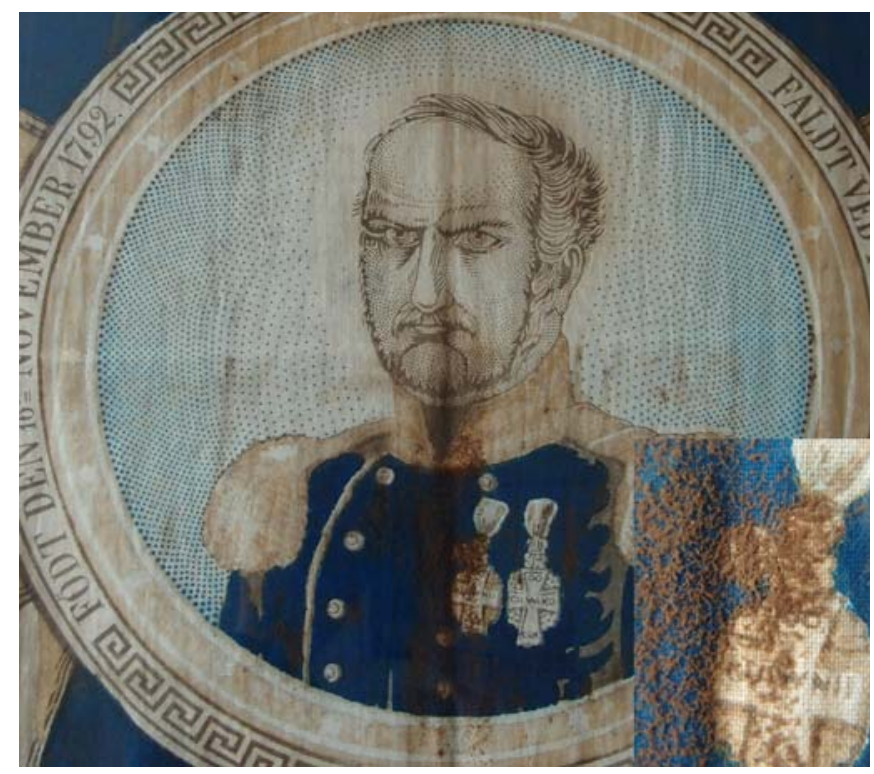

Figure 3. A textile mounted in a frame showing general Rye who died in battle 1849. Due to too humid conditions brown mold is growing especially on the chest and on one of the medals (Photo: Lise Ræder Knudsen). 


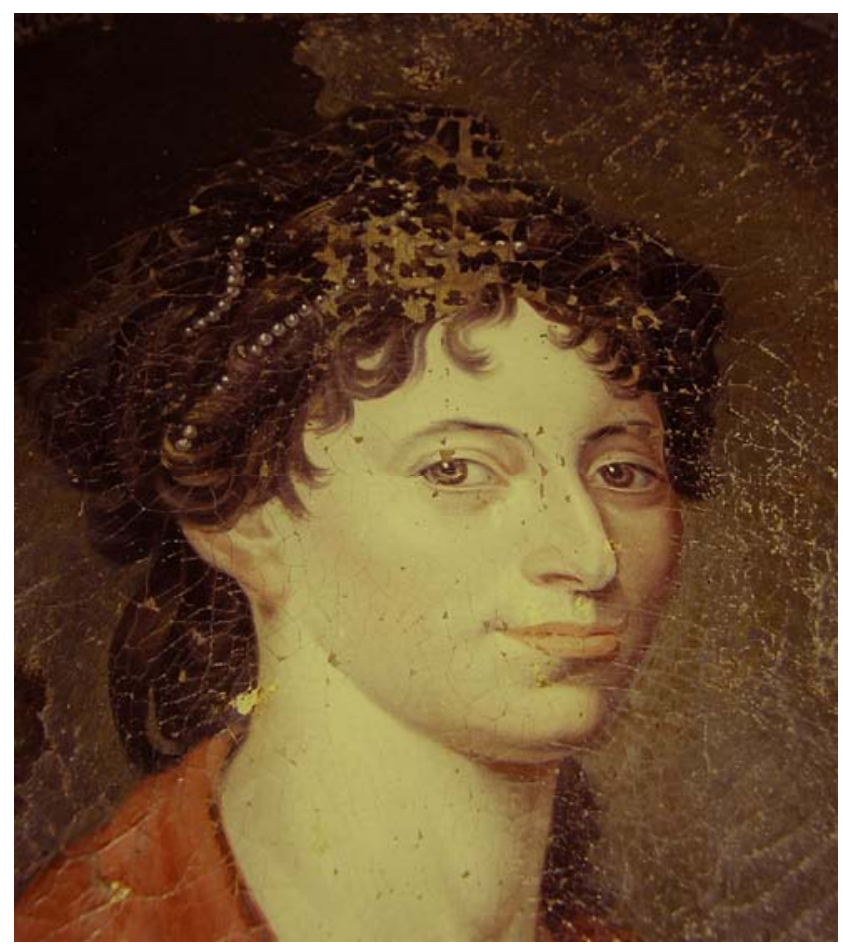

Figure 4. Portrait of Danish Queen Marie of Hessen-Kassel. The paint layers are seriously damaged due to very humid conditions. Small flakes of paint are missing especially in the hair. The paint layers and the canvas of

the paint react differently on changes in the relative humidity.. (Photo: Anette Aalling)

\section{B. Is there an alternative?}

Besides some national museums' collections or art museums with collections containing very expensive or otherwise highly profiled works of art, only few museums are able to raise the funds for building new conventional museum storage buildings with large air condition units. And any museum would like to avoid high running expenses due to high energy consumption. Thus building a conventional storage building is not a real possibility for the majority of museums in Denmark.

But within the last 12 years a new cheap low-energy museum storage building has been developed. This building combines low building expenses, very low running expenses and very high conservation quality for the collections. The building principles are described later in this article.

\section{Why are passive museum storage buildings rare?}

Since it is very difficult to predict the energy consumption necessary to keep a stable relative humidity in an existing building, the very cheap existing houses are chosen as storage for collections. These buildings are for instance old empty factories, cellars and attics which are not air tight and thus very difficult to dehumidify. The lack of knowledge of these matters among museum heads in combination with limited or downgraded budgets for preservation in general leads to cheap and insufficient solutions.

\section{Sub conclusion}

If the loss and expenses of bad storage facilities of museum buildings were known in advance, the collections would never be moved to these conditions. If we had a way to predict the costs of keeping a stable humidity in an existing building, it would be possible to choose a better solution, for instance building a low-energy museum storage building, and the benefit would be:

- Better preservation of our mutual cultural heritage.

- Much lower energy consumption and $\mathrm{CO}_{2}$ emissions.

- Less illness of museums staff due to mold.

- Much lower costs in the long run.

\section{E. Solution for sixteen regional museums}

In order to deal with the storage problems for the mutual cultural heritage, sixteen regional museums in Western Denmark in 2001 decided to construct a shared storage facility in Vejle. To reduce the construction costs and the running costs of the storage, modern industrial building techniques were combined with passive conditioning of the interior climate. The building was finished in 2003. In 2009 Department of Civil Engineering, Technical University of Denmark joined the project of designing a new and better version of the museum storage building and made an advanced investigation using the newest simulations technology. This new improved museum storage was finished in 2013 as an extension of the existing storage- and conservation lab building in Vejle.

\section{PROBLEM STATEMENT}

It is very important when designing museum storage buildings to have a much better preservation of our mutual cultural heritage and take into consideration problems, which can diminish the quality of the stored objects like temperature, relative humidity, light and several pollutants. In addition, focuses have to be at much lower energy consumption and $\mathrm{CO}_{2}$ emissions, and less illness of museums staff due to mold. Finally new design has to be cost effective, so it is attractive to choose this instead of inadequate storage facilities.

\section{A. Temperature}

Temperature is one of the most important factors affecting stored objects. Conservators take seriously into account the temperature due to the fact that basically it reflects the physical turmoil within materials [6] so for this reason temperature control is considerably important. According to theories of chemical kinetics [6] rising of the temperature practically means an increment of molecular vibration, which in turn can cause an exponentially increasing reaction rate of decay processes. In general, temperature variations may result in mechanical decay, caused by the dimensional changes from the expansion and the shrinkage of the objects (Christensen \& Janssen, 2009). It should also be stated that temperature variations might also lead to chemical decay, as chemical reactivity is enhanced [7]. The consequences are that temperature variations should be limited as much as possible and the temperature kept below $18^{\circ} \mathrm{C}[1, \mathrm{p} .4]$. 


\section{B. Relative humidity}

The relative humidity fluctuations can also lead to chemical, mechanical as well as biological decay. However, the respective response of material is immediate. The higher the relative humidity is, the higher amount of water will be absorbed by the object. On the contrary, when the relative humidity drops, the object will release moisture to the space until it reaches equilibrium with the environment. This adsorption and desorption is responsible for mechanical and chemical decay.

According to British Standard PD 5454:2012 [8] temperature and $\mathrm{RH}$ within a museum storage or archive have to be almost constant (at a value between $45-60 \%, 13-16^{\circ} \mathrm{C}$ ) with minimal tolerances around their set points $\left(5 \%, 1^{\circ} \mathrm{C}\right.$ correspondingly).

\section{Less illness of museums staff due to mold}

The Danish climatic environment contains many different species of mold - a rough estimate is some 200 different species - which are able to grow indoor. Mold produces VOC's (Volatile Organic Compounds) and various toxins, which can provoke allergic reactions. Mold spores are everywhere, but in high concentrations, some people are especially vulnerable and can have serious allergic reactions. Mold needs humid conditions and normally it will not grow below $65-70 \%$ RH. However, low quality museum storage buildings often experience periods of very humid climate beyond $70 \% \mathrm{RH}$ and the risk of severe mold attack is high. Museums stores can even constitute an increased risk because of the huge surface area of the many objects carrying a relatively large portion of mold spores if the objects have not been thoroughly cleaned before storage - which is often the case. Museums staff handles objects and works of art on a daily basis, which means they are in risk of permanent illness, and we know of several cases where museums employees were forced on early retirement due to allergic reaction towards mold. Cleaning a mold-attacked collection is very expensive. Thus, a museum storage building, which protects the collections against too high relative humidity and mold growth, will be a benefit both for the staff, the preservation and for the economy.

\section{BUILDING DESCRIPTION}

Centre for Preservation of Cultural Heritage consists of Conservation Centre Vejle and Shared Storage Facilities, and is situated in the town Vejle in Denmark. Shared Storage Facilities keeps collections of more than 20 museums and archives. The building consists of an old and a new part built in 2003 and 2013 with the purpose to store and protect valuable cultural museum collections. Because of the very special purpose of the building, modern industrial construction techniques were implemented in order to achieve a passively controlled indoor environment. In 2002 it was decided to raise a building with high-insulated building envelope, combined with high hydrothermal and thermal inertia. In 2009 collaboration between Cultural Heritage Centre, Vejle and Department of Civil Engineering, The Technical University of Denmark, Jørgen Erik Christensen was established. This section describes both the old and the new storage building including information about the main requirements during the designing process, characteristics of the building as well as information about the external dimensions.

Several parameters were examined when the existing museum storage was designed. The main requirements taken into consideration were the indoor environment, a number of objectives regarding the selection of the specific location, construction, climate regulations, security, as well as the storing system of the building, [9].

Characteristics of the building and information about the external dimensions shall be described later; but generally the building is rectangular with offices and working areas for the staff connected to the northwest façade. Included is also a conservation centre, which is connected with the stores by a building containing supporting facility such as registration office, canteen, packing room, cold store and freeze disinfection compartment [10]. Fig. 5 presents the entire cultural heritage centre, which is the conservation centre and museum storage building.

\section{A. Storage Facilities}

The old museum storage building consists of four halls: two large halls A, C and separated by a corridor, two smaller halls $\mathrm{B}$, D. The corridor was extended to the new building to enhance accessibility of each storage room [10]. $75 \%$ of the area of the four halls in the old storage building contains a mezzanine construction, Fig. 6, with a floor of metal grates. According to requirements of the collections, the four halls were divided into areas with different climates [9].

The new museum storage building consists of three approximately equal sized halls $(\mathrm{E}, \mathrm{F}, \mathrm{G})$ and a narrow corridor, which separates the old building from the new one. The exact area of each hall is shown in Fig. 7. The gross floor area is $5437 \mathrm{~m}^{2}$. The height is respectively $6.7 \mathrm{~m}$ and $7.25 \mathrm{~m}$ for the old and the new building taking into account the

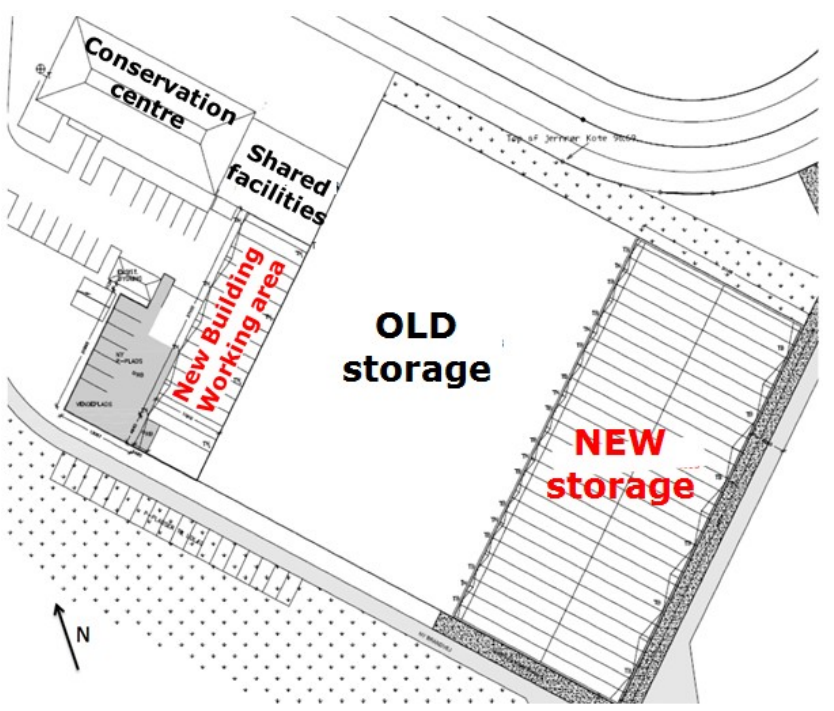

Figure 5. Centre for Preservation of Cultural Heritage. The expansion is presented with red letters. On the left of the building, there are work places for the staff, shared facilities and the conservation centre. 


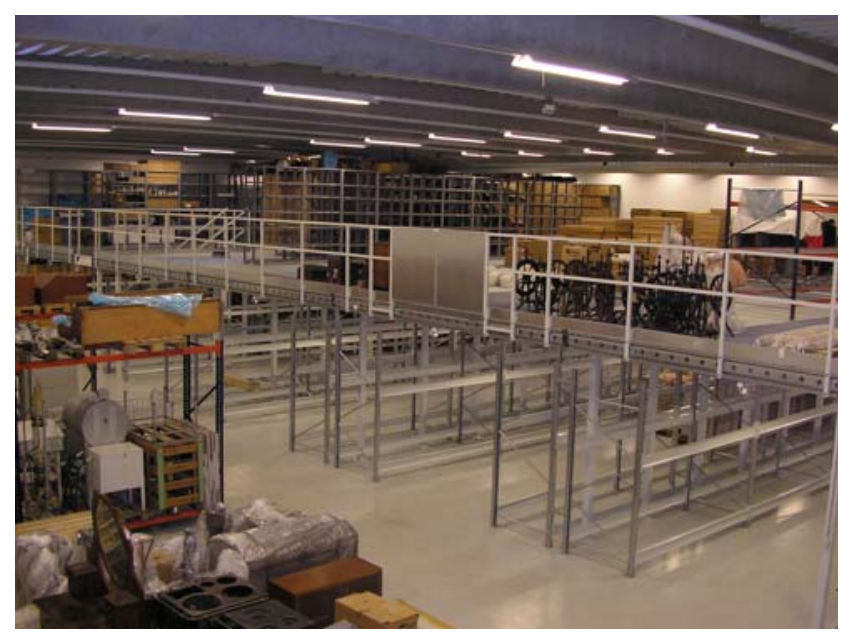

Figure 6. Picture of the interior of the museum storage showing the mezzanine construction (Photo Centre for Preservation of Cultural Heritage)

thickness of the roof and not the floor construction. In Fig. 8 the exterior view on the old and new storage building are shown after completion.

All halls are divided into climate areas, according to the specific requirements of the stored collections. In more detail, the exact area of each hall as well as the required indoor climate conditions are presented below:

- Hall A, C, D: 1060 m2, 1060 m2, 383 m2, RH: 50\% $( \pm 5 \%), \mathrm{T}: 7-18^{\circ} \mathrm{C}$ (wooden objects, paintings, mixed materials)

- Hall B: $383 \mathrm{~m} 2,40 \% \quad( \pm 5 \%) \mathrm{RH}, 10-18{ }^{\circ} \mathrm{C}$ (archaeological objects)

- Hall E, F: $619 \mathrm{~m}^{2}, 691 \mathrm{~m}^{2}, \mathrm{RH}: 50 \%( \pm 5 \%)$, T: $10-15$ ${ }^{\circ} \mathrm{C}$ (wooden objects, paintings, mixed materials)

- Hall G: 484 m2, RH: 40\% ( \pm ?\%), T: 9-15 ${ }^{\circ} \mathrm{C}$ (paper, photos, plastics)

To protect the stored objects the light level is only 70 lux in
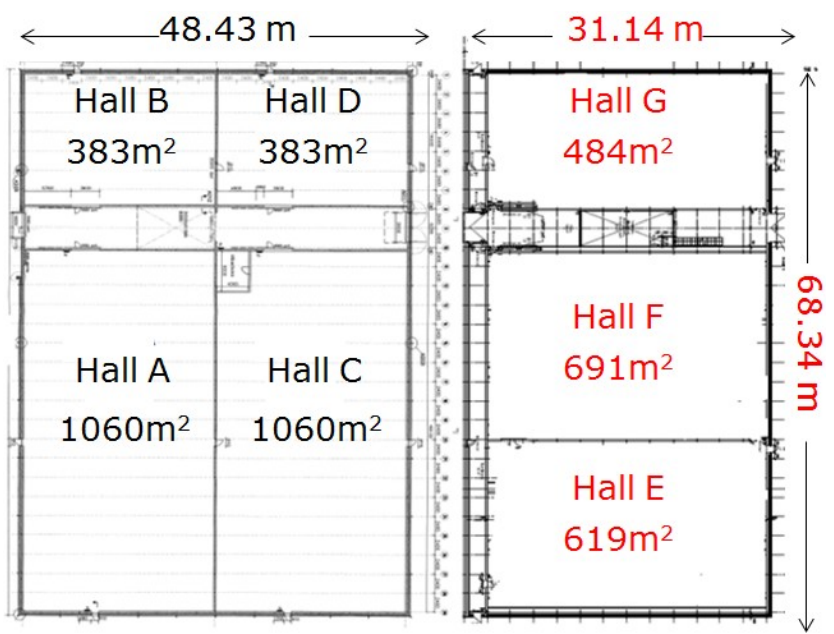

Figure 7. Floor plan and area of the OLD part, hall A-D (left) and the NEW part, hall E-G (right) part of Vejle museum storage building. the working area - other parts of the hall are not illuminated. Furthermore to save energy infrared detectors have been installed so the light only turns on when someone is in the area - this is also because lighting emits ultra violet light, which in the long run damages many of the objects.

In order to encourage people to show respect for the storage and to take responsibility for keeping it clean, light colors have been applied on the floors and the walls. Also the light colors reduce the necessary light effect in the storage halls. While the walls were painted with white paint of high permeability, the floors were painted with an epoxy paint that reduces the hygric inertia, protects the floors against mechanical wear and keeps them clean, which is an important issue for the storage.

\section{B. Systems}

The heating - cooling systems, internal gains and air tightness of the storage buildings have been designed most differently from ordinary buildings. It was meant to be full passively controlled; no heating or cooling systems were installed. However it has turned out that the storage museum building design cannot entirely mitigate the exterior high humidity levels of the climate in Denmark, which leads to unfavorable conditions for the indoor environment. Thus it has been necessary to use dehumidifiers in both buildings in order to maintain relative humidity in acceptable levels [7] respectively six hours of concentrated dehumidification between 00:00 - 06:00 and three hours from 00:00 to 03:00for the old and the new building.

\section{Concept for the new storage building}

2009-2010 Department of Civil Engineering, Technical University of Denmark did an advanced research project in order to optimize the new museum storage based on the experience from the old storage, which was finished in 2003 [7]. To achieve the aforementioned conditions with the lowest possible energy consumption a new solution was developed, which is called "passive air conditioning" [7] [11] with a more innovative concept, which is far more advanced in addition to that it opens op for a $\mathrm{CO}_{2}$ neutral solution. This concept incorporates sufficient thermal insulation, an extremely airtight building envelope and an uninsulated floor, while the focuses are less on high thermal and hygric inertia.

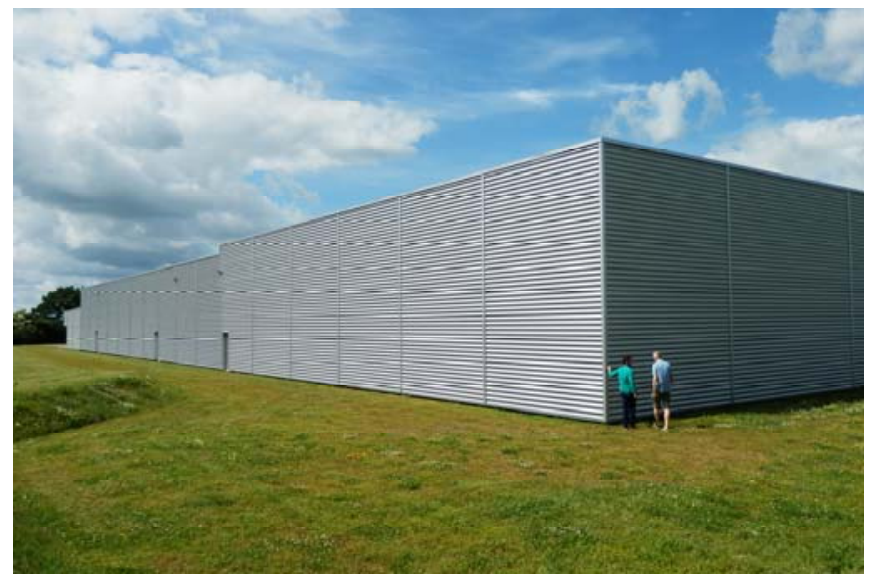

Figure 8. Exterior view on the storage building after completion. Old to the left and New to the right (Photo Christensen). 


\section{1) Thermal insulation}

Sufficient thermal insulation of the building helps to reduce the external temperature and solar radiation to have very limited influence on the indoor temperature and its amplitude [7].

\section{2) Extremely airtight building}

The extremely airtight building reduces the main energy demand, which is dehumidification. This has opened up for a new concept, where continuous dehumidification in the storage can be changed to a more optimized strategy - "concentrated dehumidification," which has been implemented from the beginning of 2014. This technique is applied for a small part during the day, while the remaining hours, hygric inertia of the building walls and the stored objects ensure that relative humidity can be left free-running, always within the acceptable levels. Hence, dehumidifiers are able to use renewable energy. Therefore, excess wind energy during the night or solar systems during the day can be implemented [12], transforming the museum storage into a nearly $\mathrm{CO}_{2}$ neutral building [4]

\section{3) Uninsulated floor}

The floor is un-insulated making it possible to use the soil as an important thermal buffer material over the season. The heat loss through the ground goes in counter phase to the heat loss through the walls, roof and by infiltration. The heat flow through the ground is negative in the wintertime - Energy transmitted to the storage, and the heat flow through the ground is positive in the summer - Energy transmitted from the storage.

\section{4) High thermal and hygric inertia}

In the former design of the old museum storage from 2003 there was also focus on high thermal and hygric inertia of the whole development, however it has been proven in [7] [11], that these elements were not so important, since the airtightness is much more important in order to keep out moisture from the exterior environment. In the old storage it has been observed that the reliability of the indoor environment entirely on full passive conditioning is shown to be an illusion [7]. Auxiliary dehumidification is inevitable in order to mitigate the exterior high humidity levels of Denmark's climate, which leads to unfavorable conditions for the indoor environment.

\section{MODELLING HEAT TRANSFER THROUGH THE GROUND}

One of the key design parameters at the museum storage is that the floor is not insulated. The reason for this will be described later in the paper. Since the floor is not insulated and soil constitutes an important thermal buffer material, it is essential important to model the thermal interaction between the indoor environment and the volume of soil below the building. This interaction is fundamentally a three-dimensional (3D) heat flow through the ground and around the building [13]. In general, dynamic building simulation programs only deal with one-dimensional (1D) modelling approaches. This means that it is necessary to develop an adequate equivalent 1D description of this $3 \mathrm{D}$ process in order to use the two programs IDA ICE and BSim for the simulation of the storage. The 1D model will consist on the inside storage boundary conditions of the concrete and leca layers finalized with a layer of soil as the outside boundary conditions on the opposite surface of the soil layer. It is important to estimate precisely the required thickness of the soil layer [14] in order to have an equivalent thermal interaction with the original 3D process.

In the process of creating an adequate equivalent 1D description of this 3D heat transfer process it is necessary first to convert the 3-D problem into a 2-D problem. Subsequently an equivalent 1D solution will be developed based on the calculated heat flow of the 2D model.

\section{A. Two-dimensional Heat Transfer}

The transforming of the 3-D problem into a 2-D problem can be done by using the formulated guidelines from [15], where the $3 \mathrm{D}$ process can be described by a $2 \mathrm{D}$ geometric model. In these guidelines the conversion is done by using the "characteristic dimension of the floor B'", defined as the area of the floor divided by the half perimeter:

$$
B^{\prime}=\frac{A}{0.5 \cdot P}
$$

Where $\mathrm{A}$ is the area of the building facing the ground $\left[\mathrm{m}^{2}\right]$, $\mathrm{B}^{\prime}$ is equivalent width of building [m], and $\mathrm{P}$ is the perimeter of building $[\mathrm{m}]$.

The space of the soil domain in terms of the thermal influences of the building is fortunately limited in 3-D space according to the guidelines from [14]. The problem can now be considered as the response of a half-infinite soil volume to excitation with a variable interior temperature over a rectangular section of the surface, and with a variable exterior temperature over the remaining part of the surface.

The 2-D heat floats have been analyzed using HEAT2 [16] providing numerical solutions for multidimensional heat transfer. Since the heat float through the ground is related to the indoor and outdoor temperature on hourly basis it has been necessary to impose the temperatures in the HEAT2 calculations indirectly through three different simulations [7], [11]: 1) Steady-state, 2) Transient interior and 3) Transient exterior. By using the principle of superposition any actual excitations can be recomposed from these three fundamental regimes.

\section{B. One-dimensional Heat Transfer - From 2-D to 1-D model}

Based on the 2-D calculations of heat flow through the ground the 1-D model can be developed, based on the same average heat flows over the year. Both models consists of the same materials (concrete and LECA), however soil thickness is different in the 1-D model. The following equation is used to calculate the soil thickness giving the same heat flow in 1-D as in the 2D model:

$$
q_{F L O O R}=U_{F L O O R} \times \Delta \mathrm{T} \Rightarrow>U_{F L O O R}=\frac{q_{F L O O R}}{\Delta \mathrm{T}}
$$

Where $\mathrm{q}_{\mathrm{FLOOR}}$ is the heat flow through the ground based on the 2-D model calculations, $\mathrm{U}_{\mathrm{FLOOR}}$ is the thermal transmittance of the floor $\left[\mathrm{W} / \mathrm{m}^{2} \mathrm{~K}\right]$, and $\Delta \mathrm{T}$ the temperature difference.

Based on this $U_{F L O O R}$ can be calculated from the equation: 


$$
U_{\text {FLOOR }}=\frac{1}{R_{I}+\frac{d_{\text {concrete }}}{\lambda_{\text {concrete }}}+\frac{d_{L E C A}}{\lambda_{L E C A}}+\frac{d_{\text {soil }}}{\lambda_{\text {soil }}}+R_{e}}
$$

Where $d_{i}$ is the thickness of each implemented material $[\mathrm{m}], \lambda_{\mathrm{i}}$ is the thermal conductivity of each implemented material $[\mathrm{W} / \mathrm{mK}]$, and $\mathrm{R}_{\mathrm{i}}, \mathrm{R}_{\mathrm{e}}$ are the thermal resistances for the indoor and outdoor surface $\left[0.13 \mathrm{~m}^{2} \mathrm{~K} / \mathrm{W}, 0.04 \mathrm{~m}^{2} \mathrm{~K} / \mathrm{W}\right]$.

The equation can be rearranged and solved for the thickness of the soil $d_{\text {soil }}$. As $\mathrm{q}_{\mathrm{FLOOR} 2 \mathrm{D}}$ should be equal to $\mathrm{q}_{\mathrm{FLOOR} 1 \mathrm{D}}$ and $\mathrm{U}_{\text {FLOOR 2D }}=\mathrm{U}_{\text {FLOOR 1D }}$ can be calculated, the soil thickness is found. As the space in this paper is limited readers with further interest can get more information in the papers [7], [11].

Since the storage consists of a rectangular section to the ground, the average distance for the heat flow differs according to either the actual position is close to the exterior wall (short distance) or the actual position is far away from the exterior wall (long distance). The accuracy of the 2-D model in HEAT2 depends how good the assumption to reality is. Two options have been explored:

1) 2-D: One surface for the entire ground (the example shown above).

2) 2. 2-D: Seven separate areas with different distance from the exterior wall (0-1 m, 1-2 m, 2-3 m, 3-5 m, 5-7 m, 7-9 m).

The heat flows through the ground in the two models have the same average heat flows over the year - this is customized by the thickness for each ground layer. However the amplitude over the year differs since version 1) does not take into account the difference in the patch the heat flow has to pass through the ground, since there is only one possibility. In version 2) with seven different layers the estimation of the heat flow is much more precise, thus resulting in a much better adaption to reality for the heat flow through the ground.

\section{Uninsulated floor - Stable temperature in storage}

As described in the problem statement a stable temperature is one of the most important factors affecting stored objects, since the consequence is mechanical decay, caused by the dimensional changes from the expansion and the shrinkage of the objects [7], [11]. This is one of the perspectives, which has been very important in the design of the museum storage.

Since the museum storage is unheated there will in winter be a heat loss to the exterior temperature (positive heat flow from the storage). Fig. 9 shows that during the winter months there is a negative heat flow through the ground, meaning that the ground is heating the museum storage. Since these two heat flows have opposite direction they will reduce the sum of the heat flows.

In the summertime the opposite effects occur since there will be a heat gain from the exterior temperature (negative heat flow from the storage) and as Fig. 9 shows during the summer months there is a positive heat flow through the ground, meaning that the ground is cooling the museum storage. Again, since these two heat flows have opposite direction they will reduce the sum of the heat flows.

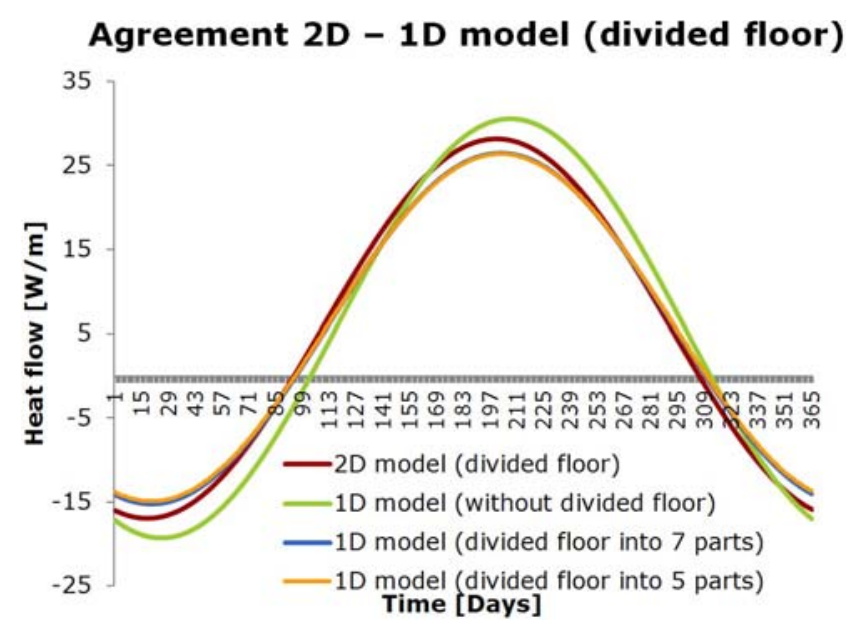

Figure 9. Comparison between results obtained from the 2D model (divided floor), 1D model (without divided floor), 1D model (divided floor) for the old storage facilities during the last simulated year (10th

All together the uninsulated floor results in a very good design and very stable temperatures inside the museum storage, which will be illustrated later when showing the simulations and measurements.

After having solved the challenge with the 3-D heat flow through the ground in the storage and showed how to convert it into a 1-D heat flow problem it is possible to use a normal building performance program to simulate the storage building.

\section{BUILDING PERFORMANCE SIMULATION}

Two building models were used in order to evaluate the indoor climate in terms of indoor air temperature levels. One was developed using the building performance program IDA ICE [17] building performance program, while an already existing model in the building performance program BSim [18] was also utilized [12]. An important aspect for both models is the thermal interaction between the interior climate and the volume of soil below the building. The uninsulated floor takes advantage of the natural heat of the ground, which is about $9^{\circ} \mathrm{C}$ [9].

The aim of using these models was to compare the outcome of the simulations with actual measurements within the storage facilities and explain reasons for possible deviations. To obtain the most accurate results, actual weather data [19] of each year were used. Hence, it would be possible to make the respective comparisons under the same weather conditions. Graphical representation as well as statistical indicators such as: coefficient of determination $\left(\mathrm{R}^{2}\right)$, coefficient of variance of the root-mean-square error (CV-RMSE) and the mean absolute error (MAE) were used to examine if deviation between the predicted temperatures and the actual measurements fall within the acceptable tolerances. It should also be stated that the comparisons took place for the period $2006-2013$.

Both models were simulated for 10 years (each time with the same weather file) in order to achieve a stable indoor climate. Results of the last year (10th year) were used for the respective comparisons. An additional a 17-year simulation 
was performed in BSim software, where the first 10 years, actual weather data of 2006 were used (in order to obtain a stable climate), while after 2006; each year was simulated with the corresponding weather file. Based on this simulation, it would be possible to examine if the predicted temperatures can be improved by taking into account the outdoor weather conditions of the previous years.

To assess if concentrated dehumidification is sufficient to maintain stable RH levels, full-scale measurements in different heights $(0 \mathrm{~cm}, 180 \mathrm{~cm}, 400 \mathrm{~cm}$, above the ground $)$ in the middle of hall $\mathrm{C}$ and $\mathrm{F}$ as well as in different spots of the same height $(180 \mathrm{~cm})$ were conducted. It is worth mentioning that the full-scale measurements within the old storage were carried out during March, while a summer month June was chosen for new storage respectively. As the indoor climate of the building is not significantly altered, a characteristic day for each period will be presented in the specific analysis.

\section{RESULTS TEMPERATURE}

Fig. 10 and Table I exemplifies the respective comparisons during 2013, where the new storage section started its operation. It is observed that both IDA ICE and BSim models provide results with a sufficient degree of accuracy, since $\mathrm{CV}$ (RMSE) and MAE are lower than 10\%. According to [20] a monthly model with $\mathrm{R}^{2} \geq 0.7$ and $\mathrm{CV}(\mathrm{RMSE}) \leq 7 \%$ can be considered as a "good model", while [21] suggests that a model with a $\mathrm{CV}(\mathrm{RMSE}) \leq 10 \%$ is a good model.

\section{Predicted \& measured temperature OLD STORAGE during 2013}
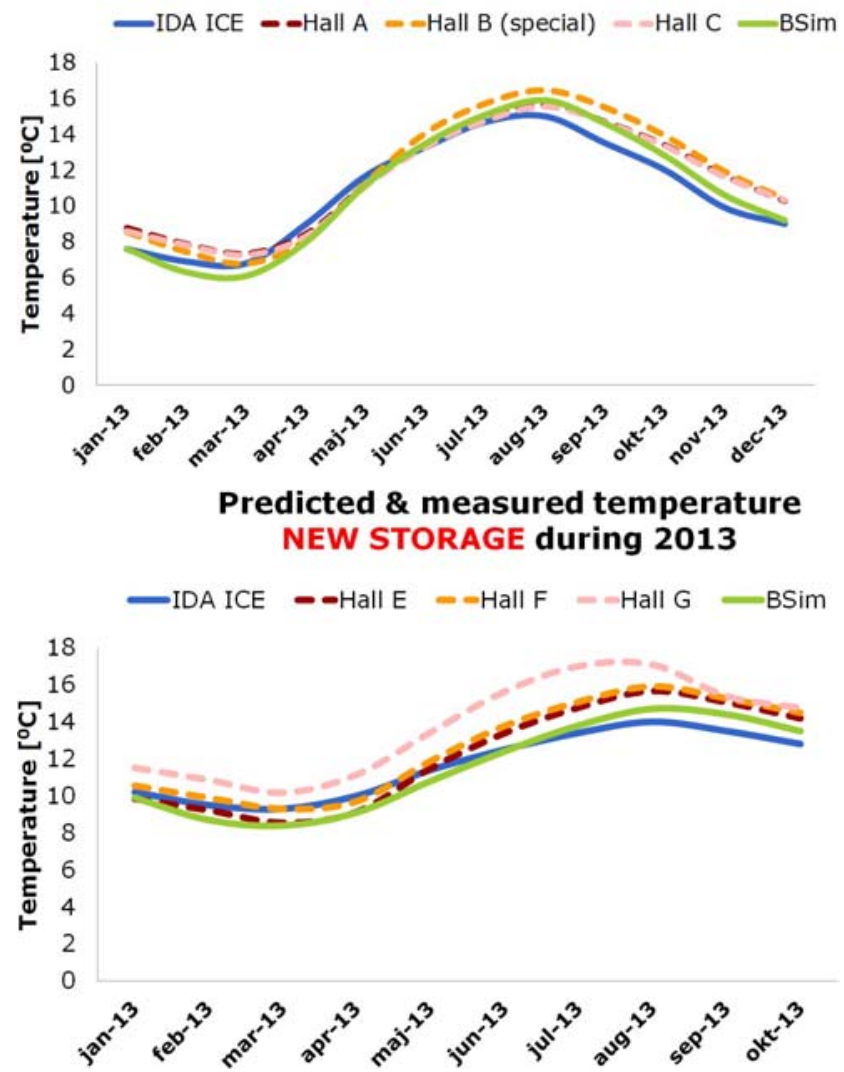

Figure 10. Predicted (IDA ICE, BSim) and measured temperatures in the old (top) and new storage (bottom) during 2012-2013.
TABLE I. R2, CV(RMSE), MAE FOR IDA ICE AND BSIM IN YEAR 2013.

\begin{tabular}{cccc}
\hline Old storage & $\mathrm{R}^{2}$ & $\begin{array}{c}\text { CV(RMSE) } \\
{[\%]}\end{array}$ & MAE [\%] \\
\hline IDA ICE & 0.88 & 8.62 & 8.05 \\
BSim & 0.94 & 7.27 & 6.97 \\
\hline \multirow{2}{*}{ New storage } & $\mathrm{R}^{2}$ & $\mathrm{CV}(\mathrm{RMSE})$ & MAE [\%] \\
\hline IDA ICE & 0.86 & 8.29 & 7.57 \\
BSim & 0.94 & 5.49 & 4.85 \\
\hline
\end{tabular}

It can also be observed that BSim predictions are "closer" to the real data during the second half of the year and more specifically after August. This can be explained by the fact that the IDA ICE ground model ISO 13370 [14] failed to take sufficiently into consideration the thermal (time) lag between the outdoor and ground temperature [22]. Maximum outdoor temperature as well as ground temperature occurs during July. However, due to the high thermal capacity of the soil, the highest ground temperature should be observed during October. In such case, ground temperature during winter months would be higher, which in turn will influence the indoor air temperature by increasing it, as the floor is not insulated.

Broadly speaking, during period 2006 - 2013, apart from 2010 it can be concluded that there is a sufficient agreement between the predicted temperatures and the real measurements.

According to Fig. 11 in the old storage in year 2010 the agreement is far from satisfactory. Both models in IDA ICE and BSim software failed to approximate the real situation, as the predicted temperatures were considerably lower, especially during the first three months. This possibly can be explained by the fact that during 2010, the average outdoor air temperature was notably lower compared to the other years of that period, Table II. Thus, the lower outdoor temperatures of the 2010 weather file seem to affect the accuracy of the results more than expected.

For that reason, an additional 17-year simulation was performed in BSim software, where the effect of the weather conditions of the previous years was taken into account. According to Fig. 11, in the new storage it can be observed that the temperature profile was drastically improved, approaching the actual values. This correction is also reflected in $\mathrm{CV}$ (RMSE) and MAE indicators. Their values were markedly decreased within the acceptable levels (lower than 10\%), as it is presented in Table III.

TABLE II. AVERAGE OUTDOOR TEMPERATURES (2006 - 2011)

\begin{tabular}{cccc}
\hline Year & 2006 & 2007 & 2008 \\
\hline Average $\mathbf{T}\left[{ }^{\circ} \mathbf{C}\right]$ & 9.1 & 9.1 & 9 \\
\hline & & & 2011 \\
\hline Year & 2009 & 2010 & 8.6 \\
\hline
\end{tabular}


Predicted \& measured temperature

OLD STORAGE during 2010
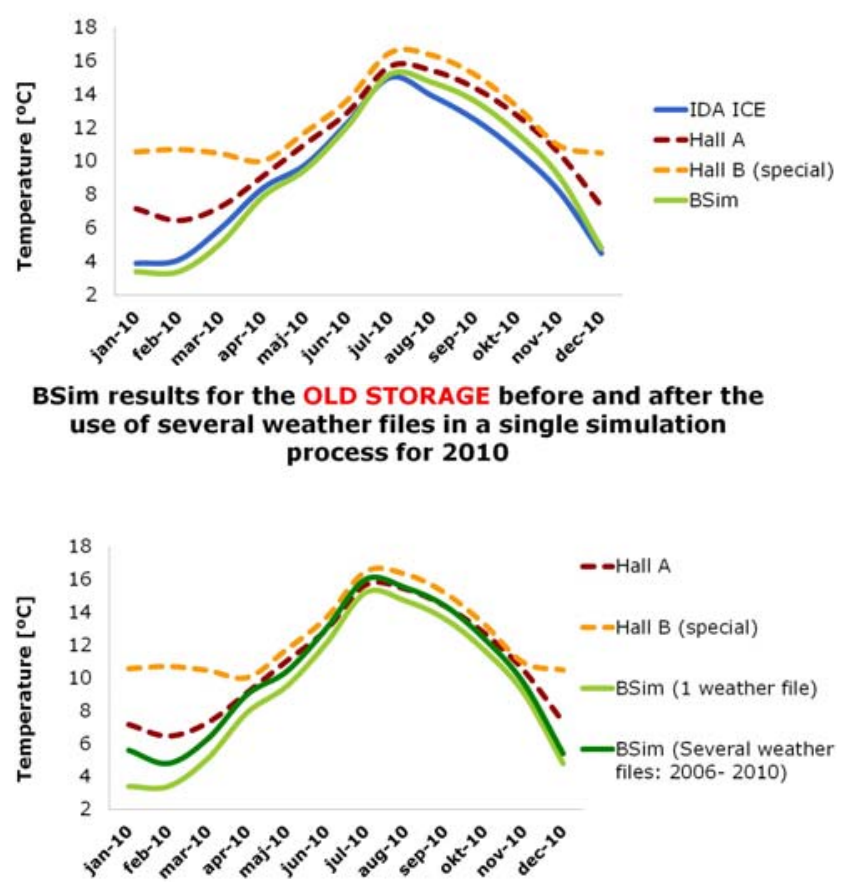

Figure 11. Predicted (IDA ICE, BSim) and measured temperatures based on (top) one; (bottom) several weather file(s).

TABLE III. R2, CV(RMSE), MAE FOR BSIM BEFORE AND AFTER THE USE OF SEVERAL WEATHER FILES

\begin{tabular}{cccc}
\hline Year: 2010 & $\mathrm{R}^{2}$ & $\begin{array}{c}\text { CV(RMSE) } \\
{[\%]}\end{array}$ & $\begin{array}{c}\text { MAE } \\
{[\%]}\end{array}$ \\
\hline $\begin{array}{c}\text { BSim } \\
\text { (1 weather file) } \\
\text { Bather files: } \\
\text { 2006-2010) }\end{array}$ & 0.75 & 17.57 & 19.35 \\
\hline
\end{tabular}

\section{RESULTS HUMIDITY}

Fig. 12 clearly indicates, the effect of concentrated dehumidification during the first hours of the day. Dehumidifiers were used from 00:00 to 06:00 every day for the old and 00:00 to 03:00 for the new storage. $\mathrm{RH}$ of the remaining hours is left "float" without any auxiliary dehumidification. In that way, $\mathrm{RH}$ levels at the end of the day were almost the same, as in the beginning of the day.

By calculating the average amplitude of $\mathrm{RH}$, it can be concluded that it is more stable at ground level compared to higher heights (old storage: $0.62 \%$ at $0 \mathrm{~cm}, 0.67 \%$ at $180 \mathrm{~cm}$ and $0.65 \%$ at $400 \mathrm{~cm}$, new storage: $0.57 \%$ at $0 \mathrm{~cm}, 1.06 \%$ at $180 \mathrm{~cm}$ and $1.61 \%$ at $400 \mathrm{~cm}$ ). This can be explained by the fact that the dehumidifiers are placed in a high spot within the storage. Thereby, the air of higher layers will be first dehumidified. It can also be observed that $\mathrm{RH}$ in lower heights

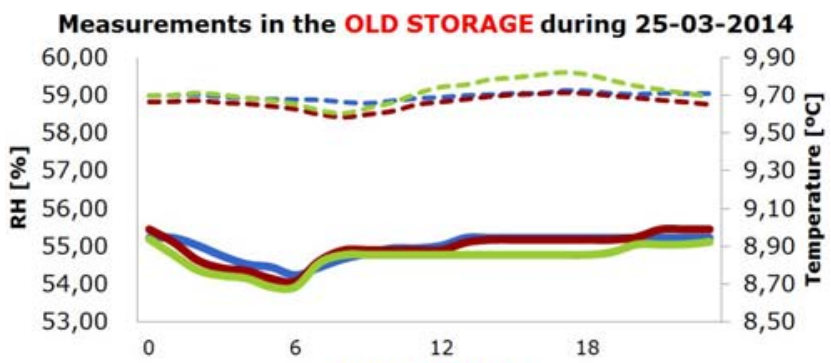

Measurements in the NEW STORAGE during 01-06-2014

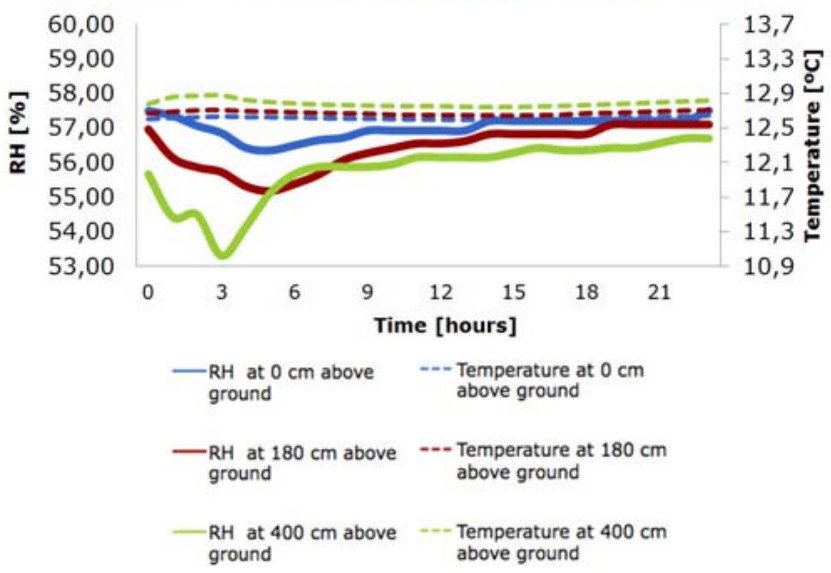

Figure 12. Full scale measurements of RH in different heights.

$(0 \mathrm{~cm}, 180 \mathrm{~cm})$ in the new storage reaches its lowest value a bit later (around 4:00 am), when the concentrated dehumidification is over. This cannot be observed in the old storage. The specific measurements in the new storage (Hall F) were carried out during June, when outdoor air is more humid compared to March. Moreover, the new storage includes lower number of stored objects compared to the old one, fact that indicates lower moisture capacity of the stored mass.

Fig. 13 shows RH fluctuations in different spots within the storage facilities. Regarding the old section, $\mathrm{RH}$ is higher close to the external wall compared to the middle and the back of the room (close to the corridor). Hence, the outdoor weather conditions have greater influence close to the external wall of the building (through the envelope leakages). Another reason for the higher relative humidity close to the south external wall is the dehumidifier's placement. It is installed in the back of the room close to the corridor. Therefore, the air of the specific area will be first dehumidified. As far as the new storage facility is concerned, significant moisture differences were not observed. Thus, it can be concluded that the high airtightness enhances the homogeneity of the indoor environment. Last but not least, the extremely stable relative humidity at the back of the room (average amplitude $0.45 \%$ compared to $1.04 \%$ for the other spots) is also associated with dehumidifier's position. 

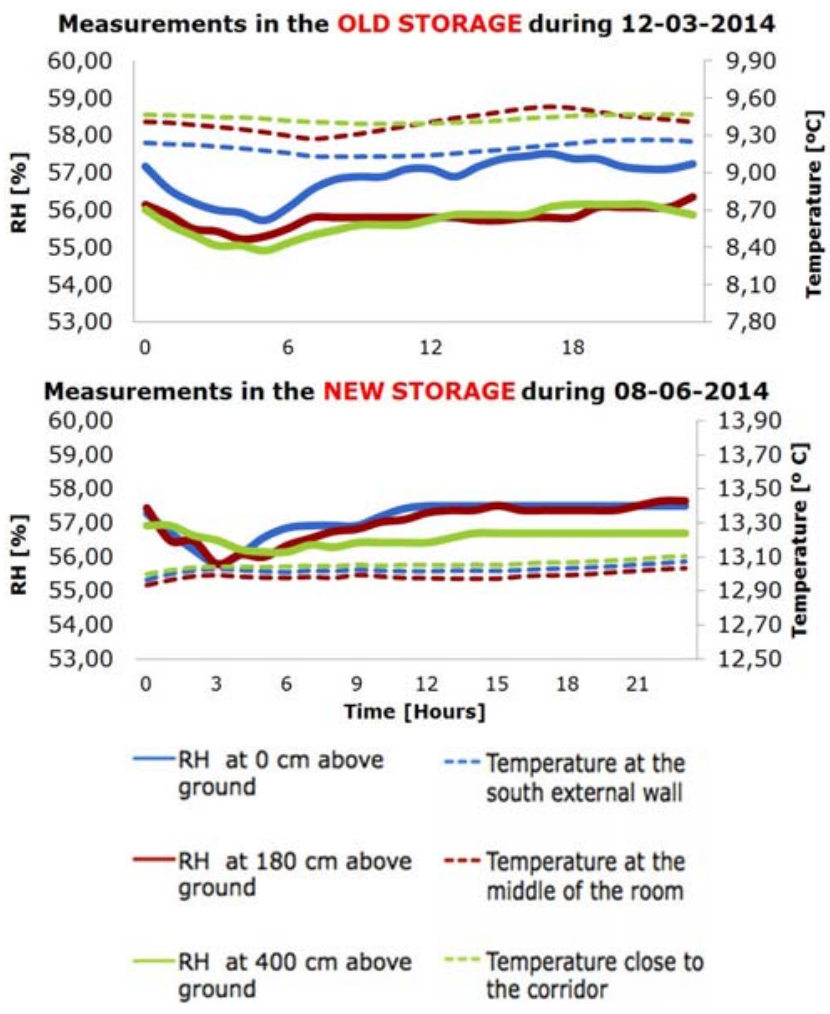

Figure 13. Full scale measurements of RH in different spots.

\section{RESULTS EVALUATION OF PERFORMANCE}

For evaluation of the performance of the new "Danish lowenergy museum storage building" from 2013, it is very important to address three parameters: Quality as storage building for cultural heritage, building expenses and running expenses of the climate control, and comparing the values of these parameters with the parameters of other buildings used for the same purpose

The quality of museum storage rooms can be measured using the Time Weighted Preservation Index (TWPI). This algorithm integrates the temperature $(\mathrm{T})$ and relative humidity $(\mathrm{RH})$ values as they change over time into a single estimate of

TABLE V. QUALITY OF DANISH MUSEUM STORAGE BUILDINGS

\begin{tabular}{|l|c|c|c|}
\hline \multicolumn{5}{|l|}{ Quality of Danish museum storage buildings with basic climate } \\
\hline Name of museum storage & Type $^{\mathbf{b}}$ & TWPI $^{\mathbf{c}}$ & Reference $^{\mathbf{a}}$ \\
\hline Royal Library, Copenhagen Stack 1 & 1 & 45 & {$[1, \mathrm{p} .8]$} \\
\hline Nationalmuseum, Ørholm hall P & 2 & 70 & {$[1, \mathrm{p} .8]$} \\
\hline Nationalmuseum Brede 9 & 2 & 60 & {$[1, \mathrm{p} .8]$} \\
\hline Ribe, Sydvestjyske Museer & 3 & 115 & {$[1, \mathrm{p} .8]$} \\
\hline Cultural Heritage Centre, Vejle 2003 & 3 & 115 & {$[1, \mathrm{p} .8]$} \\
\hline Cultural Heritage Centre, Vejle 2013 & 4 & 155 & $\begin{array}{c}\text { Data logger } \\
\text { > 1 year }\end{array}$ \\
\hline
\end{tabular}

a. Around $50 \%$ relative Humidity $(\mathrm{RH})$

b. Type: $1=$ HVAC, $2=$ HVAC without cooling, 3: Low energy: high thermal insulation, 4: Low energy, high thermal insulation and airtightness $>0,01 \mathrm{ACH}$.

c. Time Weighted Preservation Index. TWPI $>75$ : Good conditions;

$45<\mathrm{TWPI} \leq 75$ : ok conditions; TWPI $\leq 45$ : Risk of decay.
TABLE IV. BUILDING EXPENSES OF DANISH LOW-ENERGY MUSEUM STORAGE BUILDINGS

\begin{tabular}{|c|c|c|}
\hline \multicolumn{3}{|c|}{ Building expenses of Danish low-energy museum storage buildings ${ }^{\mathrm{a}}$} \\
\hline Name of museum storage & $€ p r . m^{2 b}$ & Reference \\
\hline $\begin{array}{c}\text { Ribe, Sydvestjyske Museer } \\
(2005)\end{array}$ & 1.282 & $\begin{array}{c}\text { http://magasinmanualen.dk/? } \\
\mathrm{p}=2143\end{array}$ \\
\hline $\begin{array}{l}\text { Randers, Museum Østjylland } \\
(2007)\end{array}$ & 904 & $\begin{array}{c}\mathrm{http}: / / \text { magasinmanualen.dk/? } \\
\mathrm{p}=779\end{array}$ \\
\hline $\begin{array}{c}\text { Cultural Heritage Centre, } \\
\text { Vejle (2003) }\end{array}$ & 584 & $\begin{array}{c}\text { http://magasinmanualen.dk/? } \\
\mathrm{p}=295\end{array}$ \\
\hline $\begin{array}{c}\text { Cultural Heritage Centre, } \\
\text { Vejle (2013) }\end{array}$ & 919 & $\begin{array}{c}\mathrm{http}: / / \text { magasinmanualen. } \mathrm{dk} / \text { ? } \\
\mathrm{p}=295\end{array}$ \\
\hline
\end{tabular}

a. Building expenses including shelves, but excluding site.

b. Cost not adjusted to present value, and exchange rate pr. January 2016

the cumulative effects of the environment on the rate of chemical decay [23]. Table 4 shows the TWPI of a few museum storage buildings among 17 buildings benchmarked in a project conducted by the National Museum of Denmark [1] and compares them with the new low-energy storage building raised in 2013 at Cultural Heritage Centre Vejle. The result is very clear as this low-energy building with high airtightness has a TWPI of 155 , which is much higher than the other museum storage buildings with HVAC with- and without cooling, and low-energy storage buildings with only high thermal isolation.

The building expenses of new museum storage buildings are another very important parameter in efforts to improve the storage conditions for cultural heritage. If building a new house is too expensive, old houses and factories will be chosen as storage buildings instead as described. The building expenses pr. square meter of different low-energy museum storage buildings raised during the last 13 years in Denmark are compared in Table 5. If the raise of prizes is taken into account, the low-energy building from 2013 in Vejle has the lowest building expenses.

The running expenses of the new building are even more interesting as seen in Table 6 . The fully air conditioned storage of the Royal Library uses most energy with $28 \mathrm{kWh}$ pr. $\mathrm{m}^{3} \mathrm{pr}$. year, while the new building in Vejle uses $0,6 \mathrm{kWh}$ pr. $\mathrm{m}^{3} \mathrm{pr}$. year, which is a saving of $98 \%$. Since concentrated dehumidification technique can be used for three hours at night in the new storage building in Vejle the electricity can be produced by wind power at night, where there is an overproduction of electricity from wind mills. These features make the building almost $\mathrm{CO}_{2}$ neutral.

The performance of the new building is extremely satisfying: The quality of the building as storage of cultural heritage is higher than other museum storage buildings with basic climate described in a benchmark project performed by the National Museum of Denmark [1, p.8]. The building expenses of the new building are among the lowest of the known prizes for raising low-energy museum storage buildings if the raising prize index is taken into account. Furthermore, the running expenses of keeping a climate of close to $50 \% \mathrm{RH}$ and below $18^{\circ} \mathrm{C}$ are by far the lowest among all know museum storage buildings in Denmark. 
TABLE VI. RUNNING EXPENSES OF DANISH LOW-ENERGY MUSEUM STORAGE BUILDINGS

\begin{tabular}{|c|c|c|}
\hline \multicolumn{3}{|c|}{ Running expenses of Danish low-energy museum storage buildings ${ }^{\mathbf{a}}$} \\
\hline Name of museum storage & $\boldsymbol{k W h} / \mathbf{m}^{\mathbf{3}} /$ year & Reference \\
\hline $\begin{array}{c}\text { Royal Library, Copenhagen } \\
\text { Stack 1 }\end{array}$ & 28 & {$[1, \mathrm{p} .8]$} \\
\hline Nationalmuseum, Ørholm hall P & 10 & {$[1, \mathrm{p} .8]$} \\
\hline Nationalmuseum Brede 9 & 15 & {$[1, \mathrm{p} .8]$} \\
\hline Ribe, Sydvestjyske Museer & 1,5 & {$[1, \mathrm{p} .8]$} \\
\hline $\begin{array}{c}\text { Cultural Heritage Centre, Vejle } \\
\text { 2003 }\end{array}$ & 1,5 & {$[1, \mathrm{p} .8]$} \\
\hline $\begin{array}{c}\text { Cultural Heritage Centre, Vejle } \\
2013\end{array}$ & 0,6 & $\begin{array}{c}\text { 1 year of energy } \\
\text { consumption }\end{array}$ \\
\hline
\end{tabular}

a. Energy consumption of climate control to maintain $\mathrm{RH} 50 \%$

\section{CONCLUSION}

Storage buildings for museum collections must provide a steady climate, where especially a steady relative humidity below $60 \%$ is essential. At Centre for Preservation of Cultural Heritage in Vejle a low energy storage building was raised in 2003. The building principles focused on high thermal isolation, hygric materials and an uninsulated floor. A research project initiated by DTU evaluated the 2003 building as preparation for a new extension opened in 2013. The new concept was developed on the basis of a simulation of the predicted climate of a new building. This concept incorporates sufficient thermal insulation, an extremely airtight building envelope and an un-isolated floor while it focuses less on high thermal isolation and hygric materials. The new building was raised; the climate was recorded and thus made a comparison of the simulated climate and the actual climate possible.

Based on the respective analysis it can be concluded that the weather conditions of previous years, affect the indoor environment of the following years. In particular by taking into account the outdoor weather conditions of the previous year's significantly decreases the percentage difference of the simulated and measured temperatures. What is more, new dehumidification technique is sufficient to maintain stable relative humidity levels by the end of each day. Hence, dehumidifiers operation can be supplied by renewable energy sources. Concerning the old building part, it seems that lower airtightness affects moisture content in different spots, while dehumidifiers' placement significantly affects the indoor air consistency. Hence, it may be useful to increase the airflow of the inlet circulated dehumidified air in order to minimize these dissimilarities.

The conclusion is, that this new building principle - "The Danish low-energy museum storage building" - provides very high storage quality; low building expenses and very low energy consumption with a saving of $98 \%$ compared to normal HVAC solutions. Furthermore, using the "passive air conditioning" principle, where dehumidification is only used for a few hours at night, the energy used will be provided by excess wind power from Danish windmills - and thus the building is close to $\mathrm{CO}_{2}$ neutral.

\section{ACKNOWLEDGMENT}

We thank Hans Janssen, Catholic University of Leuven, Belgium; Louis Lange Wollesen, Vejle County Cultural Heritage Centre, Denmark and master students Javier Menendez Gabielles \& Barbara Tognolo, Technical University of Denmark.

\section{REFERENCES}

[1] M. Ryhl-Svendsen, L. A. Jensen, B. Bøhm, and P. K: Larsen, "Lowenergy Museum Storage Buildings: Climate, Energy Consumption and Air Quality," UMTS Research Project, 2007-2011: Final Data Report, National Museum of Denmark, 2012.

[2] J. E. Christensen, and H. Janssen, "Passive hygrothermal control of a museum storage building in Vejle," Report R-220, Technical University of Denmark, Department of Civil Engineering, 2010.

[3] L. R. Knudsen, and K. B. Jensen, "Rapport over magasinforholdene på de statsanerkendte danske museer," [Report of magazine conditions in the state-approved Danish museums], Organisationen Danske Museer, Copenhagen, 2006, viewed 8 November 2015, from http://www.dkmuseer.dk/sites/default/files/dokumenter/Vaerktoejer/OD Ms_Magasinrapport.pdf.

[4] Report from the Danish National Audit Office on Danish state supported museums safeguarding of cultural heritage, viewed 8 November 2015 , from

http://www.rigsrevisionen.dk/media/1943212/statsanerkendte-museerssikring-af-kulturarven.pdf.

[5] "Minutes of the Culture and Leisure Committee," Copenhagen Municipality, meeting, 6 March 2015, viewed 8 November 2015, from https://www.kk.dk/edoc-agenda/18157/958c9e37-fa17-41aa-9a4a5f351caef733/ee37fb89-83c9-4e3c-be58-9ccb7793fba7.

[6] T. Padfield, "Fundamental microclimate concepts. Contribution to the conference in Copenhagen," The National Museum of Denmark, 2009.

[7] J. E. Christensen and H. Janssen, "Passive hygrothermal control of a museum storage building in Vejle," Report R-220, Technical University of Denmark, Department of Civil Engineering, 2010.

[8] British Standard, BS 5454:2012, "Recommendations for the Storage and Exhibition of Archival Documents," 2012.

[9] L. R. Knudsen, and M. H. Rasmussen, "Building a new shared storage facility for 16 museums and archives," Proceedings of the 14th Triennial Meeting in The Hague of the ICOM Committee for Conservation, The Hague, the Netherlands, September 2007.

[10] M. H. Rasmussen, "Evaluation of the climate in a new shared storage facility using passive climate control," Proceedings of 'Museum Microclimates, Copenhagen, Denmark. November 2007.

[11] H. Janssen, and J. E. Christensen, "Hygrothermal optimization of museum storage spaces," Energy and Buildings 56, 2013, pp. 169-178.

[12] J. E. Christensen and H. Janssen, "Passive hygrothermal control of a museum storage building", In Proceedings of Building Simulation 2011: 12th Conference of International Building Performance Simulation Association, 2011.

[13] J. Claesson and C. E. Hagentoft, "Heat Loss to the Ground from a Building-I," General Theory, Building and Environment, Great Britain, Vol. 26, No. 2, 1991, pp 195-208.

[14] EN ISO 13370, "Thermal performance of buildings - Heat transfer via the ground - Calculation methods," 2007.

[15] B. R. Anderson, "Calculation of the Steady-State Heat Transfer Through a Slab-on-Ground Floor," Building and Environment, Great Britain, Vol. 26, No. 4, 1991, pp 405-415.

[16] HEAT2, Iliongraenden 159, Lund S-224 72, Sweden, www.buildingphysics.com

[17] IDA Indoor Climate and Energy, IDA ICE, EQUA Simulation AB, Stockholm, 2014.

[18] BSim, Danish Building Research Institute, Aalborg Uninversity.

[19] Meausured weather data, Danish Metrological Institute, Copenhagen, Denmark 
[20] M. F. Fels, K. Kissock, M. Marean, and C. Reynold, PRISM (advanced version 1.0) user's guide, Prinston University, 1995.

[21] A. T. Reddy, et al., "Baselining methodology for facility-Level monthly energy use ASHRAE BN-97-16-4,” ASHRAE Transactions, 103(2), 1997.

[22] I. K. Auråen, "Modeling of heat exchange with the ground and analyses of the energy use for a frost proof leisure building with active solar heating," MSc Thesis, Norwegian University of Science and Technology, 2013.

[23] J. M. Reilly, D. W. Nishimura, and E. Zinn, "New tools for preservation, assessing long-term environmental effects on library and archives collections", Rochester Institute of Technology, The Commission of Preservation and Access, Washington, 1995. 